\title{
Inverted mesiodens: case report
}

\author{
Mesiodens invertido: relato de caso
}

\author{
Eneane MIRANDA 1 \\ Luciene Dornas MENDES ${ }^{1}$ \\ Sérgio Milton Martins de Oliveira PENIDO² \\ Cláudia Valéria de Sousa Resende PENIDO'
}

\begin{abstract}
Mesiodens is the term used for describing the supernumerary tooth that occurs in the maxilla, between the central incisors, in the midline region. These may erupt in the oral cavity or keep themselves impacted. Their presence causes cleaning inadequate, impossibility or difficult of the eruption of the regular teeth and having the aesthetic compromised. This paper aims at showing that early identification of supernumerary teeth, planning and correct approach, allow the preservation of the teeth and adjacent structures. This article presents the clinical case of a seven-year-old child, male, who sought for treatment complaining that teeth 11 didn't appear in the buccal cavity. Clinical and radiographic exams were done and they demonstrated the presence of the supernumerary tooth. The plan of treatment aimed at the correct localization, extraction of this supernumerary tooth and continuous follow up of the case.
\end{abstract}

Indexing terms: Tooth unerupted. Tooth supernumerary. Dental radiograph.

\section{RESUMO}

Mesiodens é o termo utilizado para denominar o dente supranumerário que ocorre na maxila, entre os incisivos centrais, na região de linha média. Esses podem irromper na cavidade oral ou ficarem impactados. A sua presença acarreta higienização inadequada, dificuldade ou impossibilidade de erupção dos dentes regulares e comprometimento da estética. O presente trabalho objetiva mostrar que a identificação precoce de dentes supranumerários, o planejamento e abordagem corretas, permitem a preservação dos dentes e estruturas adjacentes. Este artigo apresenta o caso clínico de criança de 7 anos de idade, gênero masculino, cujos pais procuraram por tratamento com queixa de não esfoliação do dente 51. Foram realizados exames clínicos e radiográficos e estes demonstraram a presença de dente supranumerário invertido. O plano de tratamento teve por objetivo a correta localização, exodontia do mesiodens que não irromperia por ser invertido; e contínuo acompanhamento do caso.

Termos de indexação: Dente não erupcionado. Dente supranumerário. Radiografia dentária.

\section{INTRODUCTION}

"Mesiodens" is the term used to describe the supernumerary tooth that occurs in the maxilla, between the central incisors, in the midline region. Supernumerary is the given denomination to the tooth which results from the hyperdontia, a developmental alteration ${ }^{1-6}$.

There are several theories suggesting possible etiological factors to this alteration in the ordinary number of teeth, as phylogenetic reversion, dichotomy of a tooth germ and hyperativity of the dental lamina6. The combination of genetic factors can also influenciate this anomaly ${ }^{3,7-10}$. The studies have shown that there is a connection in the occurrence of mesiodens with the gender, which occurrs twice more in males than in females s-3,6-7,11-12 $^{2}$
The mesiodens diagnosis, in almost cases, is established from routine panoramic and periapical radiographs ${ }^{13,14}$, and clinical exams. There are cases in which the mesiodens is associated to eruption problems, diastema, resorption of adjacent teeth and dentigerous cysts formation ${ }^{1,2,15-17}$.

This study aims at showing the clinic case about inverted mesiodens, its complications and the importance of the early diagnosis, and the ways of treatment.

\section{CASE REPORT}

A seven-year-old child, male, whose parents sought for dentist treatment complaining that "one frontal tooth there was not appeared". Anamnesis, clinical and

\footnotetext{
${ }^{1}$ Pontifícia Universidade Católica de Minas Gerais, Faculdade de Odontologia. Av. Dom José Gaspar, 500, 30535-901, Coração Eucarístico, Belo Horizonte, MG, Brasil. Correspondência para / Correspondence to: LD MENDES. E-mail: <lucienedornas@hotmail.com>.

${ }^{2}$ Universidade Federal de Minas Gerais, Faculdade de Odontologia, Departamento de Odontopediatria e Ortodontia. Belo Horizonte, MG, Brasil.
} 
radiographical exams were carried out. The patient had the teeth 21 and 51 in the oral cavity. After the clinical exam, periapical and panoramic radiographs were taken (Figure 1), in order to answer for the non exfoliation of the tooth 51. The presence of a supernumerary inverted tooth was diagnosed in the midline region. Periapical radiographs were taken by means of Clark's technique, with mesio, ortho and distoradial positioning, confirming the palatal positioning of the extra tooth, once this has moved in the same direction of the observer (Figure 2). Based on clinical and radiographical findings the supernumerary tooth was diagnosed like inverted mesiodens due to its positioning and localization. Once the mesiodens was preventing the tooth 11 of erupting, its extraction was planned and also the tooth 51. The surgical and post-surgical prodecures were carried out without major complications (Figures 3 and 4). A month after the surgery, the patient came back to the follow-up phase. A new periapical radiograph in the maxillary central incisors region was taken, and it was noticed that the postoperative results were as it was expected. Clinical and radiographical controls were scheduled periodically. The patient was kept under control during 2 years, so after 1 year, the tooth 11 has already been in positioning (Figures 5 and 6). At present, the patient is in preventive maintenance phase and it will be send to orthodontic treatment at the suitable moment if it's necessary.

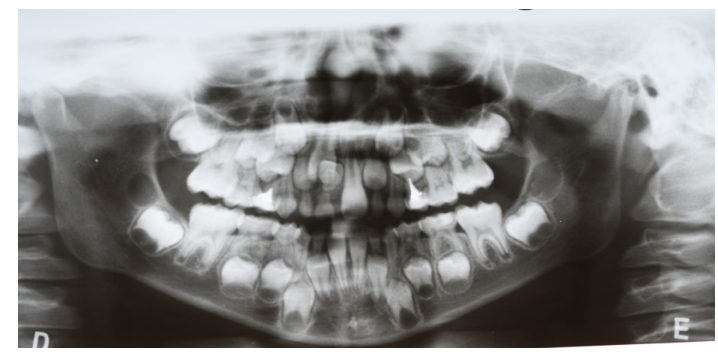

Figure 1. Initial panoramic radiographical exam.

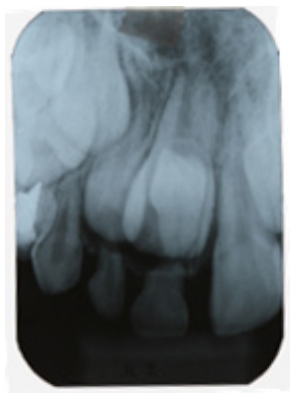

Figure 2. Periapical radiographs - Clark's technique Note: A) Mesioradial; B) Orthoradial; C) Distoradial.

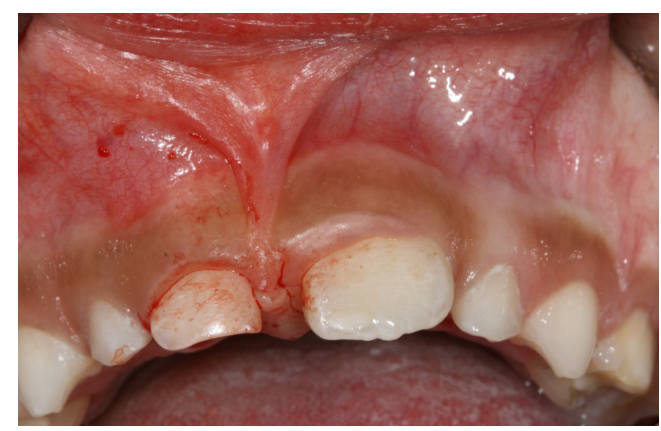

Figure 3. Labial sulcular incision preserving papila.

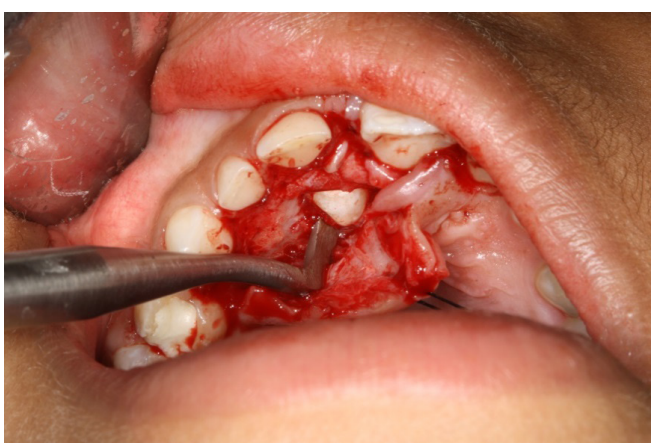

Figure 4. Surgical access to the palatine. Extraction of the extra numerary tooth.

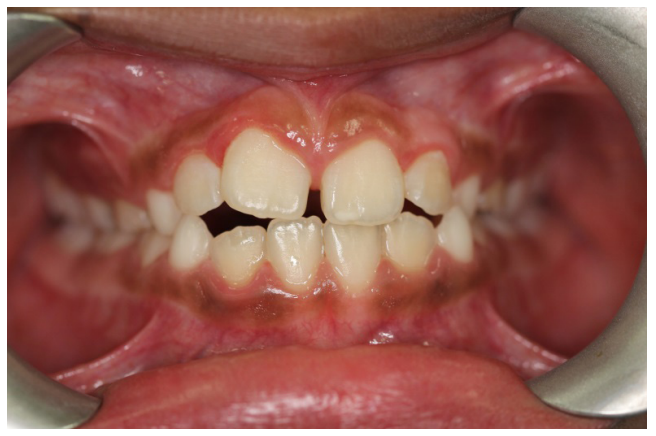

Figure 5. Tooth 11 integrate in the cavity, together with the tooth 21.

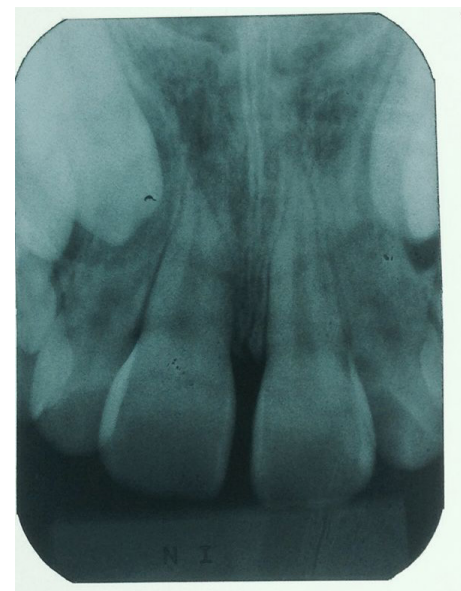

Figure 6. Periapical radiograph - teeth 11 e 21 


\section{DISCUSSION}

Hyperdontia is a developmental alteration which results in an increase of the number of teeth, and having supernumerary the term used to this extra tooth ${ }^{4}$, which has reported prevalence between $0.15 \%$ and 3,9\% ${ }^{11}$. Inverted mesiodens is a supernumerary tooth that occurs among the maxillary central incisors, with inverted position. The most common form among the three related in the literature: ordinary, inverted and horizontal|4,9-10. According to the literature, the shown case reports the presence of tooth among the upper incisors and in the inverted position, adding to the statistics that $80 \%$ up to $90 \%$ of the supernumerary occur in the maxilla ${ }^{4}$. Of these, almost half is found in the anterior region with the prevalence of $15 \%$ to $1.9 \%{ }^{11}$. Among the possible causes for this positioning are the cleft palates, tumors, trauma, cleft lip, malformation and genetic factors ${ }^{8}$, which in the shown case were not confirmed in the anamnesis and in the clinical exams carried out. Some studies associate the alteration in the regular number of teeth to the phylogenetic reversion and hyperactivity of the dental lamina ${ }^{7}$ and also with dichotomy of a tooth germ ${ }^{6}$. These causes were neither mentioned in the anamnesis nor confirmed with the exams carried out, raising this way the possibility of their parents' omission or ignorance in relation to the genetic feature, or the association of this anomaly to causes that are not yet known.

The patient from the presented case has corroborated studies that show the occurrence twice superior in males, related to female. These works don't show justifications for this fact. ${ }^{1}$

Knowing about different radiographic techniques, makes it possible to the surgeon identify, locate and planning correctly the treatment, creating conditions so that this treatment is done safety, avoiding surgical complications and also with the permanent tooth, decreasing the damages that this anomaly can cause to the patient ${ }^{9-10,12-13,15,17}$. In this case, periapical and panoramic radiographs were taken ${ }^{5,14}$, which offered enough images to the treatment diagnosis and planning. Thus, there was

\section{REFERENCES}

1. Kim SG, Lee SH. Mesiodens: a clinical and radiographic study. J Dent Child. 2003;70(1):58-60.

2. GündüZ K, Celenk P, Zengin Z, Sümer P. Mesiodens: a radiografic study in children. J Oral Sci. 2008;50(3):287-91. doi: 10.2334/ josnusd.50.287 not the need to identify the computerized tomography, even being that, a technique indicated to surgical conservative and safe planning and procedure ${ }^{17}$. Despite its image production quality, it is a higher cost and complexity exam, and there was no justification to this investment and the patient's wear out, once the safety to the procedure diagnosis and execution have already been assured with the radiographic exam. The right position of the extra tooth in relation to the permanent teeth is importante so that the surgery to its extraction does not commit the permanent teeth, which was possible by the use of Clark's technique.

As in more than $80 \%$ of the cases $^{16}$, where the extraction was denoted, the extra tooth was removed, since it was not part of the regular number of neither deciduous nor permanent teeth. The presence of supernumerary teeth can allow the development of cysts both dentigerous or primary, root reabsorption of adjacent tooth ${ }^{17}$, or the supernumerary incursion to the nasal cavity ${ }^{6}$ Furthermore, the inverted position of the mentioned tooth leaves no doubt about the surgery indication, since there was neither the possibility to natural eruption nor the extraction by alveolar via ${ }^{16}$.

The post-operative control to follow the tooth eruption evolution is as important as diagnose and carried out the surgery of the mesiodens. The removal of the supernumerary tooth itself it's not enough so that the permanent tooth sets in its right position. In this case, the tooth 11 takes on its right position in the arch and there was no need to orthodontic intervention.

\section{CONCLUSION}

The presented case shows that the correct mesiodens diagnosis allows the treatment and the case solution, minimizing complications and enabling a better prognosis.

\section{Collaborators}

E MIRANDA, execution of surgery and article writing. LD MENDES and SMMO PENIDO, article writing assistance. CVSR PENIDO, pratical and writing orientation

3. Nagaveni NB, Umashankara KV, Sreedevi, Reddy BP, Radhika NB, Satisha TS. Multi-lobed mesiodens with a palatal talon cusp: a rare case report. Braz Dent J. 2010;21(4):375-8. doi: 10.1590/ S0103-64402010000400016

4. Ghogre $P$, Singh VD. Management of an impacted inverted mesiodens associated with a large circumferential type of dentigerous cyst: a rare case report with one-year follow-up. Int J Case Rep Images. 2014;5(1):80-5. doi: 10.5348/ijcri-2014-01445-Cl-18 
5. Choi HM, Han JW, Park IW, Baik JS, Seo HW, Lee JH, et al. Quantitative localization of impacted mesiodens using panoramic and periapical radiographs. Imaging Sci Dent. 2011;41(2):63-9. doi: 10.5624/isd.2011.41.2.63

6. Anil S, Beena VT, Raji MA, Sreela LS, Vijayakumar T. Morphometric analysis of premaxillary supernumerary teeth. J Indian Dent Assoc. 1992;63(8):337-41.

7. Russel KA, Folwarczna MA. Mesiodens - diagnosis and management of a common supernumerary tooth. J Can Dent Assoc. 2003;69(6):362-6.

8. Cogulu D, Yetkiner E, Akay C, Seckin O, Alpoz R. Multidisciplinary management and long-term follow-up of mesiodens: a case report. J Clin Pediatr Dent. 2008;33(1):63.

9. Atasu $M$, Orguneser $A$. Inverted impaction of a mesiodens: a case report. J Clin Pediatr Dent. 1999;23(2):143-6.

10. Patel K, Patel N, Venkataraghavan K. Management of a dentigerous cyst associated with inverted and fused mesiodens: a rare case report. J Int Oral Health. 2013;5(4):73-7.

11. Acharya S. Facial talon cusp in a mesiodens: a rare occurrence. Eur J Gen Dent. 2015;4(3):145-9. doi: 10.4103/2278-9626.163340

12. Kumar DK, Gopal KS. An epidemiological study on supernumerary teeth: a survey on 5,000 people. J Clin Diagn Res. 2013;7(7):1504-7. doi: 10.7860/JCDR/2013/4373.3174.
13. Santos VB, Souza AB, Sapata VM, Correa GO, Marson FC, Oliveira e Silva $C$. Prevalência radiográfica de dentes não irrompidos e supranumerários. RGO, Rev Gaúch Odontol. 2013;61(1):10711

14. Freitas DQ, Tsumurai RY, Machado Filho DNSP. Prevalência de anomalias dentais de número, tamanho, forma e estrutura. RGO, Rev Gaúch Odontol. 2012;60(4):437-41.

15. Vosough Hosseini S, Moradzadeh M, Lotfi M, Ala Aghbali A, Fattahi S. Dentigerous cyst associated with a mesiodens: a case report. J Dent Res Dent Clin Prospects. 2011;5(2):76-8. doi $10.5681 /$ joddd. 2011.016

16. Lara TS, Lancia M, Silva Filho OG, Garib DG, Ozawa TO Prevalence of mesiodens in orthodontic patients with deciduous and mixed dentition and its association with other dental anomalies. Dental Press J Orthod. 2013;18(6):93-9.

17. Dalledone M, Tassi-Junior PA, Souza JF, Losso EM. Mesiodens surgery at deciduous and permanent dentition. RSBO 2015;12(1):94-7. 